\title{
THE MECHANISM OF ACTION OF SOLUTION FLUORIDE UPON THE DEMINERALIZATION RATE OF HUMAN ENAMEL
}

\author{
N. A. MIR and W. I. HigucHI \\ College of Pharmacy, University of Michigan, Ann Arbor, Michigan 48104, U.S.A. \\ and
}

J. J. HEFFERREN

American Dental Association, Chicago, Illinois 60611, U.S.A.

\begin{abstract}
Summary-Equations have been derived and computations carried out for the demineralization rates of tooth enamel employing the "Fluorapatite" model. The model assumes that when hydroxyapatite is exposed to a low fluoride concentration, a layer of fluorapatite is formed around the apatite crystal and this fluorapatite is assumed to be the thermodynamic governing phase during dissolution. The demineralization rates have been obtained as a function of the fluoride ion concentration, the hydrogen ion concentration, the total buffer concentration, the diffusion coefficients of all the species involved, the dissociation constant of buffer acid $\left(K_{\mathrm{a}}\right)$, and the solubility products of fluorapatite and hydroxyapatite.

The "Fluorapatite" model has been critically examined with experimental data obtained with synthetic apatites and enamel powder. Experiments were carried out as a function of solution fluoride concentration, the common ions (calcium and phosphate) and $\mathrm{pH}$. In the case of synthetic sample, TVA (P.D.), all of the experiments were in quantitative agreement with the model when a fluorapatitc solubility product valuc of $1 \times 10^{-130}$ to $1 \times 10^{-132}$ was used in conjunction with a hydroxyapatite solubility product value of $1 \times 10^{-130}$ to $1 \times 10^{-132}$. In the case of the powdered enamel studies values of $K_{\mathrm{fap}} \simeq 1 \times 10^{-119}$ and $K_{\text {hap }} \simeq 1 \times 10^{-118}$ gave good consistency with experiments. It was found necessary to consider the influence of fluoride initially present in the enamel samples to achieve the best agreement of the data with model.

The "Fluorapatite" phase has been interpreted as that formed by the isomorphous substitution of the surface hydroxyls by the fluoride rather than by the reprecipitation of a "true" fluorapatite phase upon the original hydroxyapatite crystals.

These studies have been found to be consistent with those reported earlier (HIGUCHI et al., $1969,1965)$. Thus it may be concluded that a single a priori physical model has thus far described all of the experimental data on enamel and synthetic apatite dissolution rates in a self-consistent manner.
\end{abstract}

\section{INTRODUCTION}

STUdies were recently initiated (HIGUCHI et al., 1965, 1969) on the quantitative mechanistic approach to the understanding of the various factors influencing the enamel demineralization rate and enamel reactions in general. These have led to physical models that have quantitatively related the enamel dissolution rate to the important variables and parameters entering into the theory by means of the appropriate mathematics. 
In the previous studies (HiguchI et al., 1965, 1969) it was shown that the initial dissolution rates of block enamel, powdered enamel and synthetic apatites in various acidic buffers adhere very closely to a physical model which assumes that hydroxyapatite is the thermodynamic governing phase. It was shown that the dependency of the demincralization rate upon pII, buffer concentration, buffer type, common ion (calcium and phosphate) concentrations could be quantitatively explained by this model.

The present communication is an extension of our previous work, and considers the role of solution fluoride in enamel demineralization reactions which has been a topic of interest in relation to dental caries (VOLKER, 1939; KNUTSON and ARMSTRONG, 1943; MANLY and BiBBY, 1949; MCCANN, 1953; BRUdeVold et al., 1957; WALSH et al., 1957; LEACH, 1959; MALAOWALla and MYERS, 1962; BRUdeVOLD et al., 1963; GrAY, 1965; JENKINS, 1966). A model is proposed and analyzed with experimental data in which fluorapatite is assumed to be the thermodynamic governing phase during dissolution in acidic media. As will be seen, this model is quantitatively in good agreement with all the experiments involving both enamel and synthetic apatites under a wide range of conditions.

\section{MATERIALS AND METHODS}

\section{"Fluorapatite" model}

The key assumption in this model is that when hydroxyapatite is exposed to a low concentration of fluoride in acidic media a thin layer of fluorapatite is formed around the hydroxyapatite crystals by the following reaction

$$
\mathrm{Ca}_{10}\left(\mathrm{PO}_{4}\right)_{6}(\mathrm{OH})_{2}+2 \mathrm{~F}^{-} \rightarrow \mathrm{Ca}_{10}\left(\mathrm{PO}_{4}\right)_{6}(\mathrm{~F})_{2}+2\left(\mathrm{OH}^{-}\right) \text {. }
$$

Such a layer may occur either by the surface precipitation of fluorapatite upon the hydroxyapatite crystals or by the exchange of surface hydroxyls by fluoride. Further assuming that fluorapatite will be the thermodynamically governing phase during this dissolution the model illustrated in Fig. 1 may be proposed. The approximate equations for this model, have been dcrived employing a method similar to that proposed by Higuchi et al. (1965) in their work on enamel dissolution in acidic media not containing fluoride.

When enamel is brought into contact with a stirred acid buffer solution containing fluoride the following processes take place. The acid buffer molecules and hydrogen ions diffuse toward the enamel surface across a liquid diffusion layer of constant thickness, $h$. These ions and molecules meet the $\mathrm{PO}_{4}^{3-}$ and $\mathrm{HPO}_{4}^{2-}$ which are diffusing outward from the enamel surface through the diffusion layer. Thus the following reactions are expected to occur in the diffusion layer.

$$
\begin{array}{ll}
\mathrm{HPO}_{4}^{2-}+\mathrm{H}^{+} \rightarrow \mathrm{H}_{2} \mathrm{PO}_{4}^{-} & \phi_{1} \\
\mathrm{HPO}_{4}^{2-}+\mathrm{HB} \rightarrow \mathrm{H}_{2} \mathrm{PO}_{4}^{-}+\mathrm{B}^{-} & \phi_{2} \\
\mathrm{H}^{+}+\mathrm{B}^{-} \rightarrow \mathrm{HB} & \phi_{3}
\end{array}
$$




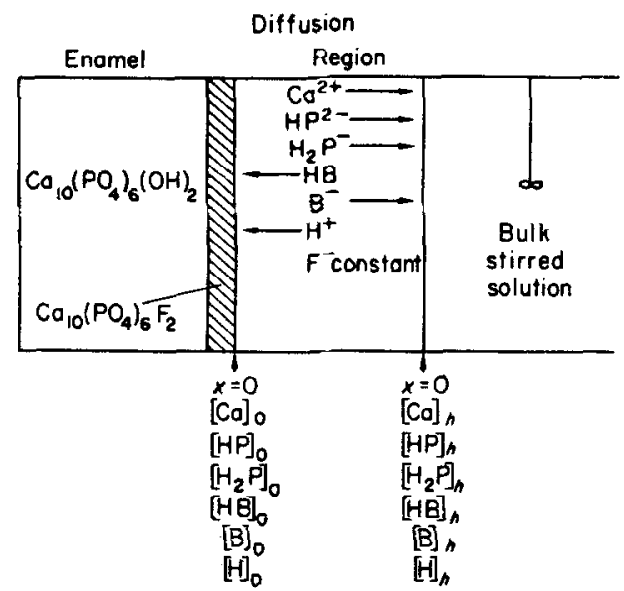

Fig. 1. Model for solution fluoride action on enamel dissolution rates in acid buffer solutions. Solution adjacent to surface is in equilibrium with fluorapatite phase.

The equilibrium expressions governing in the diffusion layer are:

$$
\begin{gathered}
K_{\mathrm{B}}=\frac{\left[\mathrm{H}^{+}\right]\left[\mathrm{B}^{-}\right]}{[\mathrm{HB}]} \text { at } x>0 \\
K_{2 \mathrm{P}}=\frac{\left[\mathrm{H}^{+}\right]\left[\mathrm{HPO}_{4}^{2-}\right]}{\left[\mathrm{H}_{2} \mathrm{PO}_{4}^{-}\right]} \text {at } x>0 \\
K_{3 \mathrm{P}}=\frac{\left[\mathrm{H}^{+}\right]\left[\mathrm{PO}_{4}^{3-}\right]}{\left[\mathrm{HPO}_{4}^{2-}\right]} \text { at } x>0 .
\end{gathered}
$$

At the interface $(x=0)$ the solubility product of fluorapatite,

$$
K_{\text {fap }}=[\mathrm{Ca}]_{0}^{10}\left[\mathrm{PO}_{4}\right]_{0}^{6}[\mathrm{~F}]_{0}^{2}
$$

is also assumed to be obeyed.

The products of the reaction then diffuse out of the diffusion layer into the bulk solution along with calcium and the remaining unreacted phosphate species. Thus the following equations, which are essentially the expressions for Fick's law of diffusion in the steady-state, may be written:

$$
\begin{aligned}
& D_{\mathrm{Ca}} \frac{\mathrm{d}^{2}\left[\mathrm{Ca}^{2+}\right]}{\mathrm{d} x^{2}}=\mathrm{O} \\
& D_{\mathrm{HP}} \frac{\mathrm{d}^{2}\left[\mathrm{HPO}_{4}^{2-}\right]}{\mathrm{d} x^{2}}-\phi_{1}-\phi_{2}=0 \\
& D_{\mathrm{H}_{2} \mathrm{P}} \frac{\mathrm{d}^{2}\left[\mathrm{H}_{2} \mathrm{PO}_{4}^{-}\right]}{\mathrm{d} x^{2}}+\phi_{1}+\phi_{2}=0
\end{aligned}
$$




$$
\begin{aligned}
& D_{\mathrm{HB}} \frac{\mathrm{d}^{2}[\mathrm{HB}]}{\mathrm{d} x^{2}}-\phi_{2}+\phi_{3}=0 \\
& D_{\mathrm{B}} \frac{\mathrm{d}^{2}\left[\mathrm{~B}^{-}\right]}{\mathrm{d} x^{2}}+\phi_{2}-\phi_{3}=0 \\
& D_{\mathrm{H}} \frac{\mathrm{d}^{2}\left[\mathrm{H}^{+}\right]}{\mathrm{d} x^{2}}-\phi_{1}-\phi_{3}=0 \\
& D_{\mathrm{F}} \frac{\mathrm{d}^{2}\left[\mathrm{~F}^{-}\right]}{\mathrm{d} x^{2}}=\mathrm{O} .
\end{aligned}
$$

The $D$ 's in these equations are the effective diffusion coefficients for those species indicated by the subscripts. The $\phi$ 's are the rates of reaction per unit volume defined by equations (2).

Integrating equations (3-8) over the limits $x=\mathrm{O}$ and $x=h$, and using the appropriate conditions (HrGucH et al., 1965, equations (12-19) in this reference), and the reaction given by equations ( 1 and 10),

$$
\mathrm{Ca}_{10}\left(\mathrm{PO}_{4}\right)_{6}(\mathrm{OH})_{2}+2 \mathrm{~F}^{-} \rightarrow \mathrm{Ca}_{10}\left(\mathrm{PO}_{4}\right)_{6}(\mathrm{~F})_{2}+2\left(\mathrm{OH}^{-}\right)
$$

and

$$
2\left(\mathrm{OH}^{-}\right)+\mathrm{Ca}_{10}\left(\mathrm{PO}_{4}\right)_{6}(\mathrm{~F})_{2}+8 \mathrm{H}^{+} \rightarrow 10 \mathrm{Ca}^{2+}+6 \mathrm{HPO}_{4}^{2-}+2 \mathrm{~F}^{-}
$$

one obtains the same set of equations given by HigucHI et al. (1965, equations (12-19) in this reference). In addition the integration of equation (9) gives

$$
D_{\mathrm{F}} \frac{\mathrm{d}[\mathrm{F}]}{\mathrm{d} x}=\mathrm{O}
$$

which states that fluoride is neither consumed nor generated during the steady-state dissolution period.

The second integration of these equations over the limits $x=0$ to $x=h$ then gives the two equations which describe the hydroxyapatite dissolution rate, $G$, for this model.

$\left[\mathrm{H}^{+}\right]_{0}^{6}=\frac{\left[K_{3 \mathrm{P}}\right]^{6}\left[\mathrm{~K}_{2 \mathrm{P}}\right]^{6}}{K_{\mathrm{fap}}}\left[\left[\mathrm{Ca}^{2}\right]_{h}+\frac{G h}{\mathrm{D}}\right]^{10}\left[\mathrm{~F}^{-}\right]^{2}\left[\frac{\frac{0 \cdot 6 G h}{\mathrm{D}}+\left[\mathrm{HPO}_{4}^{2-}\right]_{h}+\left[\mathrm{H}_{2} \mathrm{PO}_{4}^{-}\right]_{h}}{K_{2 \mathrm{P}}+\left[\mathrm{H}^{+}\right]_{0}}\right]^{6}$

$$
\begin{aligned}
0.8 G h=\mathrm{D}\left[\mathrm{H}_{2} \mathrm{PO}_{4}^{-}\right]_{h}+\mathrm{D}[\mathrm{HB}]_{h} & -\frac{0.6 G h+\mathrm{D}\left[\mathrm{HPO}_{4}^{2-}\right]_{h}+\mathrm{D}\left[\mathrm{H}_{2} \mathrm{PO}_{4}^{-}\right]_{h}}{1+\frac{K_{2 \mathrm{P}}}{\left[\mathrm{H}^{+}\right]_{0}}} \\
& -\frac{\mathrm{D}[\mathrm{HB}]_{h}+\mathrm{D}\left[\mathrm{B}^{-}\right]_{h}}{1+\frac{K_{\mathrm{B}}}{\left[\mathrm{H}^{+}\right]_{0}}}
\end{aligned}
$$


In these final two equations (12 and 13) all of the concentration terms with the subscript, $h$, are known, these being the bulk solution concentrations. The only quantities which are unknown are $\left[\mathrm{H}^{+}\right]_{0}, G$ and $h .\left[\mathrm{H}^{+}\right]_{0}$ is the hydrogen ion concentration at the enamel surface $(x=0), G$ is the congruent dissolution rate of hydroxyapatite expressed as moles of calcium transported per unit area, and $h$ is the diffusion layer thickness. $G h$ can be treated as a single unknown, as these two terms always occur together in equations (12 and 13). Hence for a certain set of values for all of the knowns one may eliminate $\left(\mathrm{H}^{+}\right]_{0}$ and calculate $G h$ from the two equations using successive approximation methods involving a digital computer.

\section{General considerations in the design of experiments}

The main goal of this study was to establish the applicability of the model to data obtained with synthetic apatite preparations and with a powdered enamel sample. In view of the success enjoyed by the hydroxyapatite model in describing the dissolution rate data of various apatite samples in the absence of fluoride, it was hoped that the same type of analysis might be carried out in the present case.

Preliminary examinations of the theory (equations 12 and 13) revealed that, if the model is correct, the dissolution rate should be very sensitive to the fluoride, calcium, and phosphate concentrations in the dissolution media. Thus these variables, along with $\mathrm{pH}$, were considered to be primary ones for the analysis of the proposed "fluorapatite" model. Experiments were designed accordingly.

For the synthetic apatites the TVA sample described earlier (HrGucH et al., 1969) and a Victor commercial sample were used. However most of the synthetic apatite work was restricted to the TVA sample, as it was considered to be much better from the standpoint of purity and crystallinity. The same batch of powdered enamel as that involved in the previous studies (HIGuchI et al., 1969) was used in this work. It contained $74-75 \mathrm{ppm}$ of fluoride. Studies on block enamel dissolution rates in the presence of solution fluoride underway in these laboratories will be reported later.

\section{Analytical procedures}

Methods for the analyses of phosphate and calcium used in the present work already been described (HIGUCHI et al., 1969). Calcium was determined by atomic absorption spectrophotometry and phosphate by a colorimetric procedure.

Fluoride concentrations were determined by the method developed at Burdick \& Jackson Laboratories (Muskegon, Michigan, U.S.A.) with slight modifications. The reagent used was Amadac $F$., which is a blended mixture of partially hydrated sodium acetate, acetic acid, stabilizers, lanthanum nitrate, and alizarin complexan, the lanthanum and complexan being equimolar. A 10 per cent solution of the reagent in 60 per cent alcohol was made and filtered to provide a very clear solution prior to use.

As it was found that phosphate interferes, it was decided to equalize all the samples with respect to phosphate in a given batch. This worked very satisfactorily. Known aliquots of standard fluoride solution and unknown sample solutions were pipetted into $25-\mathrm{ml}$ volumetric flasks. As the colour is sensitive to $\mathrm{pH}$ and ionic strength the buffer used in the initial run was added to the known fluoride standard samples. Then 
the required quantity of phosphate standard solution was added to each of the flasks in the batch under analysis, so as to equalize the phosphate contents (which were determined prior to fluoride analysis) in every sample. Before making up the volume to $25 \mathrm{ml}$ with distilled water, $5 \mathrm{ml}$ of Amadac F. solution were added to each flask. The colour developed after half an hour (stable up to $1 \mathrm{hr}$ ) and was read on the spectronic 20 (Bausch \& Lomb, Inc., Rochester, New York, U.S.A.) colorimeter, or the Hitachi-Perkin Elmer spectrophotometer model 139 (Perkin Elmer Corp., Norwalk, Conn., U.S.A.), at a wavelength of $620 \mathrm{~m} \mu$ against a reagent blank.

\section{Experimental procedure for dissolution studies}

The procedure was essentially that described earlier (Higuchi et al., 1969). One hundred milligrams of the enamel powder or the synthetic apatite powder were transferred to a $250-\mathrm{ml}$ volumetric flask clamped to the arm of a Burrell Wrist action shaker. This flask dipped into the water bath maintained at $30^{\circ} \mathrm{C} \pm 0 \cdot 2^{\circ} \mathrm{C}$. Then $200 \mathrm{ml}$ of the required buffer equilibrated previously to $30^{\circ} \mathrm{C}$ were transferred and at the same time the shaker and a timer were started. The shaking conditions were kept constant throughout the study. Samples of 10 or $5 \mathrm{ml}$ were withdrawn at various intervals by means of a $10 \mathrm{~cm}^{3}$ hypodermic syringe and needle, and were filtered through Millipore filters (Millipore Filter Corp., Bedford, Mass., U.S.A.) $(0 \cdot 22 \mu$ pore size) contained in Swinny filter holders. These samples were then analyzed for calcium, phosphate, and fluoride.

In some cases $75 \mathrm{mg}$ of the apatite sample was used and in these cases the buffer used was $150 \mathrm{ml}$.

Experiments were carried out at $\mathrm{pH} 4.5$ in $0.05 \mathrm{M}$ acetate buffers. Also a few runs were made at $\mathrm{pH} 6 \cdot 0$. The rates were much slower at $\mathrm{pH}=6 \cdot 0$ and therefore the uncertainties were greater in calculating the rates from the data. Most of the runs were done in duplicate. The agreement between two repeat runs was generally within 1-3 per cent. The average values of these runs were used to calculate the dissolution rates.

\section{EXPERIMENTAL RESULTS}

The data obtained from dissolution experiments were plotted as "amount of hydroxyapatite dissolved (mg) in $200 \mathrm{ml}$ or $150 \mathrm{ml}$ of buffer" vs. time. The amounts of hydroxyapatite dissolved were calculated on the basis of both calcium and phosphate analyses whenever both were possible. Good stoichiometry, i.e. congruent dissolution, was found, except for the enamel and Victor apatite experiments at high (In these cases it was established that $\mathrm{CaF}_{2}$ was precipitating) ( $\widetilde{>} 100 \mathrm{ppm}$ ) fluoride levels (MIR, 1967). However because of the somewhat better precision of the phosphate analysis, the data obtained by it was used to calculate the dissolution rates whenever possible.

Figures 2 and 3 are the results of typical experiments with powdered enamel and TVA apatite respectively. These particular data show the influence of solution fluoride upon the dissolution rates. Changes in scale on both axes for these plots should be noted. From such plots the initial dissolution rates were calculated from the slopes 


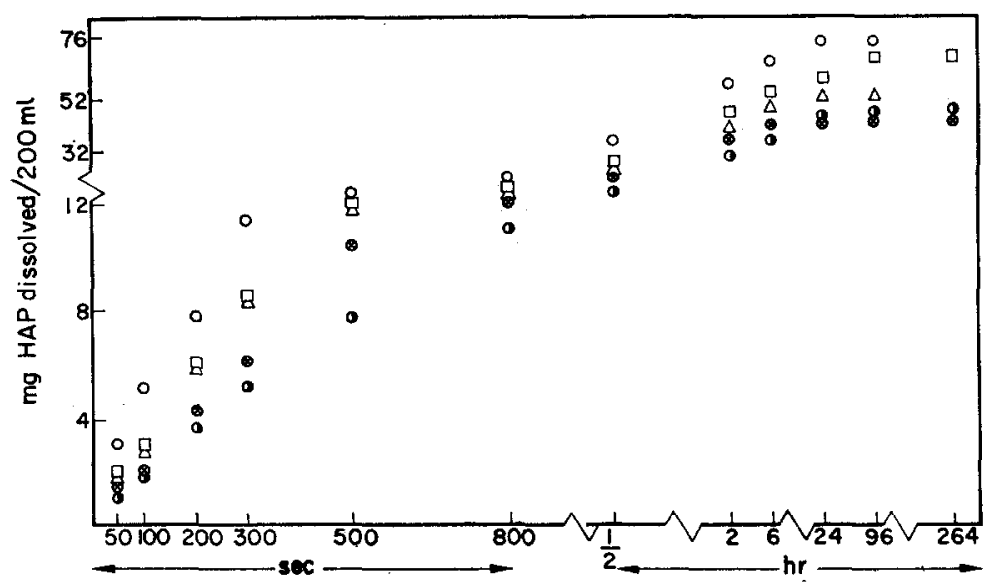

FIG. 2. Dissolution rate of enamel powder in fluoride solution, $\mathrm{pH} 4 \cdot 5,0 \cdot 05 \mathrm{M}$ acetate buffer. Key for fluoride concentration: $O=0.0 \mathrm{ppm} ; \square=0.1 \mathrm{ppm} ; \triangle=1.0 \mathrm{ppm}$; $\otimes=10 \cdot 0 \mathrm{ppm} ; 0=100 \cdot 0 \mathrm{ppm}$.

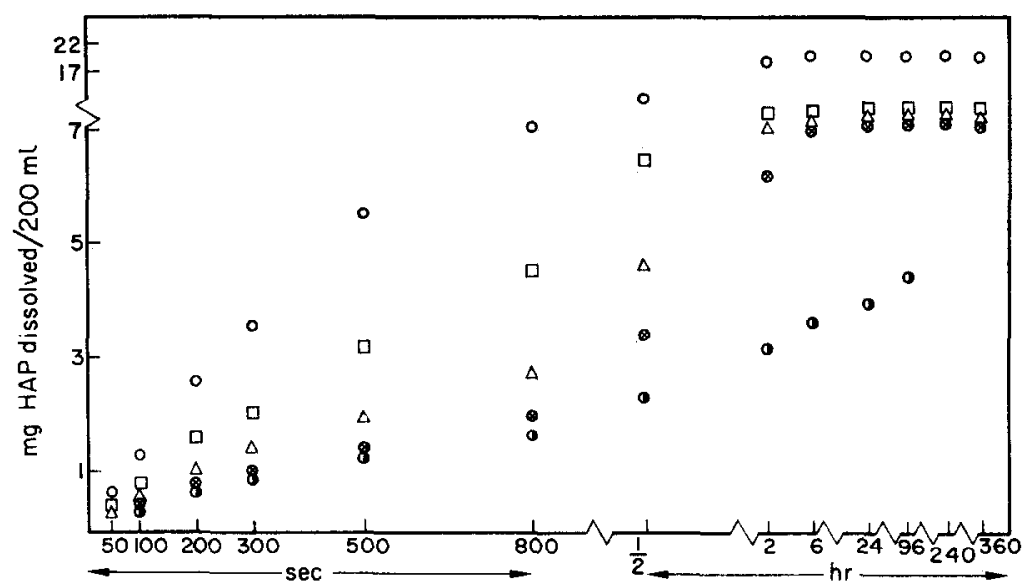

Fig. 3. Dissolution rate of TVA (15 per cent predissolved) apatite sample in fluoride solution, $\mathrm{pH} 4 \cdot 5,0.05 \mathrm{M}$ acetate buffer. Key for fluoride concentration: $\mathrm{O}=0.0 \mathrm{ppm}$; $\square=0.1 \mathrm{ppm} ; \Delta=1.0 \mathrm{ppm} ; \otimes=10.0 \mathrm{ppm} ; D=100.0 \mathrm{ppm}$.

determined from the first 800-1800 sec data points, where only 5-10 per cent of the solid had dissolved. These were then compared at the same per cent of hydroxyapatite dissolved. For these short time periods the concentration buildup of the reaction products in the bulk solution were small enough so that it may be neglected.

Let us, for example, take the dissolution data of enamel powder in $\mathrm{pH} 4 \cdot 5,0.05 \mathrm{M}$ acetate buffer (refer to Fig. 2) and calculate the relative rates between the $0 \mathrm{ppm}$ and $0.1 \mathrm{ppm}$ fluoride runs. First plot all of the initial points up to $1800 \mathrm{sec}$ dissolution for this set, and draw smooth curves through them. Then compare the slopes, say at 2 
per cent dissolved, at 3 per cent, 4 per cent and so on. In general the relative rates obtained in this manner were found to be constant up to 5-10 per cent dissolution.

The dissolution data for $0.1 \mathrm{ppm}$ and $1.0 \mathrm{ppm}$ fluoride concentration levels were similarly plotted and the rates were calculated in the same way. This process was carried out for all the fluoride lcvels in any one sct of dissolution experiments or for all the common ion concentration levels at a given fluoride concentration.

In the experiments with the TVA sample it was difficult to obtain good initial slopes due to an early abrupt curvature in the amount dissolved vs. time plots (HIGUCHI $e t$ al., 1969). Therefore a 15 per cent predissolved sample which is referred to as TVA (P.D.) was used.

Influence of solution fluoride on the initial dissolution rate of TVA (P.D.) apatite sample (common ions present)

The experimental relative rates showing the effect of common ions, phosphate and calcium, in $\mathrm{pH} 4.5,0.05 \mathrm{M}$ acetate buffers containing $0.1 \mathrm{ppm}$ and $1.0 \mathrm{ppm}$ fluoride are given in Figs. 4 and 5 respectively. The ordinate for these plots refers to the ratio of the initial dissolution rates in the common ion solution containing fluoride to that with no common ion in the medium.

The theoretical fluorapatite model predictions were made as follows. The zero common ion rate at a particular fluoride concentration was calculated by means of equations (12 and 13). This value was set equal to 100 per cent of the ordinate. Then using the same equations, the rates for different concentrations of common ion at the particular fluoride concentration were calculated. The curves A and B in Figs. 4 and 5

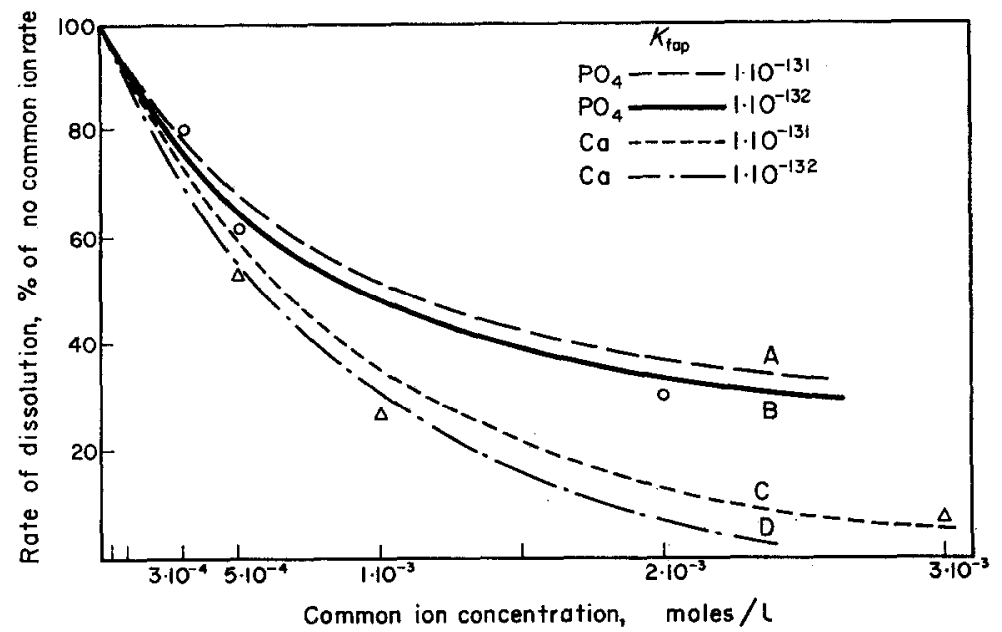

FIG. 4. Effect of common ions on the initial dissolution rate of TVA(P.D.) apatite sample in $0.1 \mathrm{ppm}$ fluoride solution, $\mathrm{pH} 4 \cdot 5,0.05 \mathrm{M}$ acetate buffer. Key: $\mathrm{O}=$ experimental data for phosphate ions; $\triangle=$ experimental data for calcium common ions. The curves $A$ and $B$ indicate theory for the phosphate common ion effect when $K_{\text {fup }}=1 \times 10^{-131}$ and $1 \times 10^{-132}$ respectively, while curves $C$ and $D$ predict theory for the calcium common ion effect when the same values of $K_{\mathrm{fap}}$ are used $\left(1 \times 10^{-131}\right.$ and $\left.1 \times 10^{-132}\right)$. 


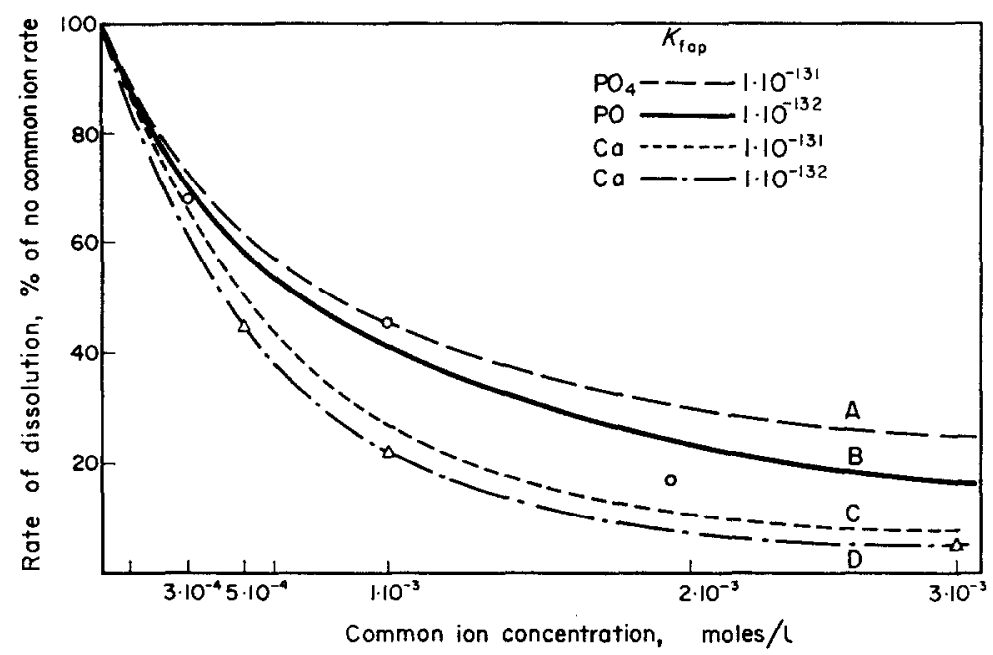

FIG. 5. Effect of common ions on the initial dissolution rate of TVA (P.D.) apatite sample in $1.0 \mathrm{ppm}$ fluoride solution, $\mathrm{pH} 4.5,0.05 \mathrm{M}$ acetate buffer. Key: $\mathrm{O}=\mathrm{Ex}$ perimental data for phosphate common ions; $\Delta=$ experimental data for calcium common ions. The curves $A$ and $B$ indicate theory for the phosphate common ion effect when $K_{\mathrm{fap}}=1 \times 10^{-131}$ and $1 \times 10^{-132}$ respectively, while curves $\mathrm{C}$ and D predict theory for the calcium common ion effect when the same values for $K_{\text {fap }}$ are used $\left(1 \times 10^{-131}\right.$ and $\left.1 \times 10^{-132}\right)$.

represent the theoretical predictions for the phosphate common ion effect, when $K_{\text {fap }}=1 \times 10^{-131}$ and $1 \times 10^{-132}$ respectively are employed, while curves C and D show the theoretical predictions for the effect of calcium common ion when the same values of $K_{\text {fap }}$ are used $\left(1 \times 10^{-131}\right.$ and $\left.1 \times 10^{-132}\right)$.

The values used for the different parameters in equations (12 and 13) for the theoretical calculations are given in Table 1 . The corrected constants in Table 1 were obtained by correcting the thermodynamic constants with selected activity coefficients.

TABLE 1. EquILIBRIUM CONSTANTS FOR THEORETICAL CALCULATIONS

\begin{tabular}{lll}
\hline Parameter & Thermodynamic constants & Corrected constants* \\
\hline$K_{2 \mathrm{p}}$ & $6 \cdot 3 \times 10^{-8} \mathrm{moles} / 1$ & $2 \cdot 0 \times 10^{-7}$ \\
$K_{3 \mathrm{p}}$ & $4 \cdot 7 \times 10^{-113}$ & $1 \cdot 4 \times 10^{-12}$ \\
$K_{\mathrm{B}}$ (Acetic) & $1 \cdot 75 \times 10^{-5}$ & $2 \cdot 2 \times 10^{-5}$ \\
$K_{\text {hap }}$ Enamel & $1 \times 10^{-116}$ & \\
$K_{\text {fap }}$ Enamel & $1 \times 10^{-120}$ & \\
$K_{\text {hap }}$ TVA & $1 \times 10^{-119}$ & \\
$K_{\text {fap }}$ TVA & $1 \times 10^{-121}$ & \\
& $1 \times 10^{-132}$ & \\
& $1 \times 10^{-130}$ & \\
\end{tabular}

All diffusion coefficients taken as $1 \times 10^{-5} \mathrm{~cm}^{2} \mathrm{sec}^{-1}$.

* Based on activity coefficient correction estimated for ionic strength $=0.1 \rightarrow 0.2$. 
Except for the $K_{\text {fap }}$ values these are essentially the same as those used in the earlier studies (HIGUCHI et al., 1969, 1965).

It can be seen that at both solution fluoride levels $(0 \cdot 1 \mathrm{ppm}$ and $1.0 \mathrm{ppm})$ and for both phosphate and calcium common ions, the experimental results are in very good agreement with the model when $K_{\text {fap }}$ of $1 \times 10^{-131}$ to $1 \times 10^{-132}$ is used. As will be seen in the next section, experiments involving no common ions are also in good agreement with the fluorapatite model employing the same $K_{\text {fap }}$ values $\left(1 \times 10^{-131}\right.$ to $1 \times 10^{-132}$ ).

Influence of solution fluoride on the initial dissolution rate of TVA (P.D.) apatite sample (no common ion present)

Figure 6 shows the comparison between the experimental and the theoretical data on the influence of solution fluoride upon the initial dissolution rate of TVA (P.D.) apatite in $\mathrm{pH} 4 \cdot 5,0.05 \mathrm{M}$ acetate buffer. The ordinate in this case refers to the ratio

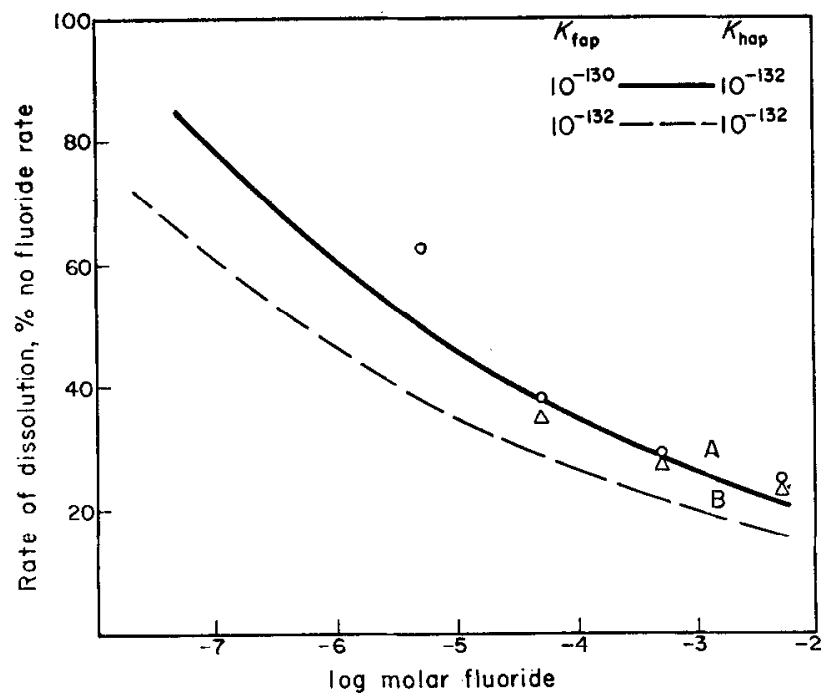

FIG. 6. Effect of solution fluoride on the initial dissolution rate of TVA (P.D.) apatite sample in $\mathrm{pH} 4.5,0.05 \mathrm{M}$ acetate buffer. Key: $O=$ TVA (P.D.) Apatite sample I; $\Delta=$ TVA (P.D.). Apatite sample II. Curve A represents theory when $K_{\text {fap }}=1 \times 10^{-130}$ and $K_{\text {hap }}=1 \times 10^{-132}$ are employed, while curve B represents theory when $K_{\text {fap }}=1$ $\times 10^{-132}$ and $K_{\text {hap }}=1 \times 10^{132}$ are used.

of the initial dissolution rate in the fluoride solution to that with no fluoride in the medium.

The theoretical model predictions in these cases were calculated in the following manner. The zero fluoride rate was calculated by the hydroxyapatite model (HIGUCHI et al., 1969, equations (13 and 14) in this reference). This was set equal to 100'per cent on the ordinate. The theoretical predictions for the different concentrations of fluoride 
were calculated by means of equations (12) and (13) of the present model with Table 1 values for the parameters. The solid curve A shown in Fig. 6 represents the theoretical calculations employing $K_{\text {fap }}=1 \times 10^{-130}$ and $K_{\text {hap }}=1 \times 10^{-132}$, while the broken curve B represents the theory when $K_{\text {hap }}=1 \times 10^{-132}$ and $K_{\text {fap }}=1 \times 10^{-132}$ are used. It should be recalled that these values for $K_{\text {hap }}$ and $K_{\text {fap }}$ have already been independently checked and tested with the model. The present $K_{\text {fap }}$ value agrees well with the findings in the last section. The present value for $K_{\text {hap }}$ is also in good agreement with earlier work (HIGUCHI et al., 1969) in which no fluoride was present in the

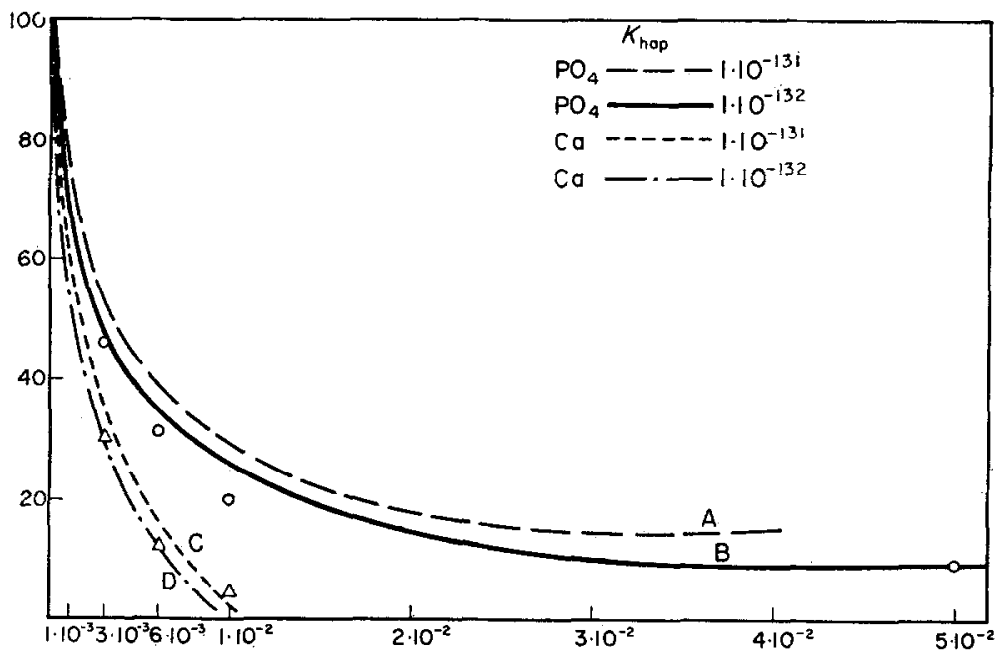

Fig. 7. Effect of common ions on the initial dissolution rate of TVA (P.D.) apatite sample in $\mathrm{pH} 4 \cdot 5,0.05 \mathrm{M}$ acetate buffer. Key: $\mathrm{O}=$ experimental data for phosphate common ions; $\Delta=$ experimental data for calcium common ions. The curves $A$ and $B$ predict theory for the phosphate common ion effect when $K_{\mathrm{hap}}=1 \times 10^{-131}$ and $1 \times$ $10^{-132}$ respectively, while the curves $C$ and $D$ predict theory for the calcium common ion effect with the same values of $K_{\text {hap }}\left(1 \times 10^{-131}\right.$ and $\left.1 \times 10^{-132}\right)$.

TVA (P.D.) experiments (see Fig. 7). Thus these independent tests of model applicability show that all of the experimental data obtained thus far with the TVA.(P.D.) sample may be described by a single a priori unified physical model.

Influence of solution fluoride on the initial dissolution rate of enamel powder (common ion present)

Figures 8 and 9 show the influence of the common ions, calcium and phosphate, upon the enamel powder initial dissolution rate in $\mathrm{pH} 4 \cdot 5,0.05 \mathrm{M}$ acetate buffer containing $1.0 \mathrm{ppm}$ and $10.0 \mathrm{ppm}$ fluoride respectively. The experimental data points are based on the initial rates determined as described before from the amount of hydroxyapatite dissolved vs. time plots.

The axes in Figs. 8 and 9 refer to percentage of no common ion initial dissolution 


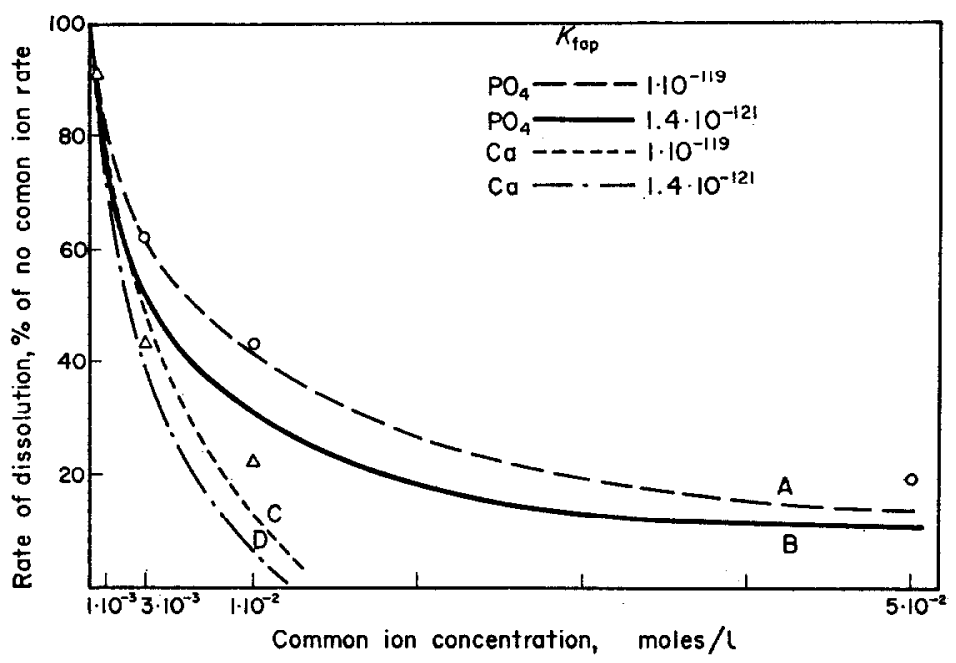

Fig. 8. Effect of common ions on the initial dissolution on rate of enamel powder in $1 \cdot 0$ ppm fluoride solution, $\mathrm{pH} 4 \cdot 5,0 \cdot 05 \mathrm{M}$ acetate buffer. Key: $\mathrm{O}=$ experimental data for phosphate common ions; $\Delta=$ experimental data for calcium common ions. The curves $A$ and $B$ represent theory for the phosphate common ion effect when $K_{\text {fap }}=$ $1 \times 10^{-119}$ and $1.4 \times 10^{-121}$ respectively, while the curves $C$ and $D$ indicate theory for the calcium common ion effect when the same values of $K_{\text {fup }}$ are used $\left(1 \times 10^{-119}\right.$ and $1.4 \times 10^{-121}$.

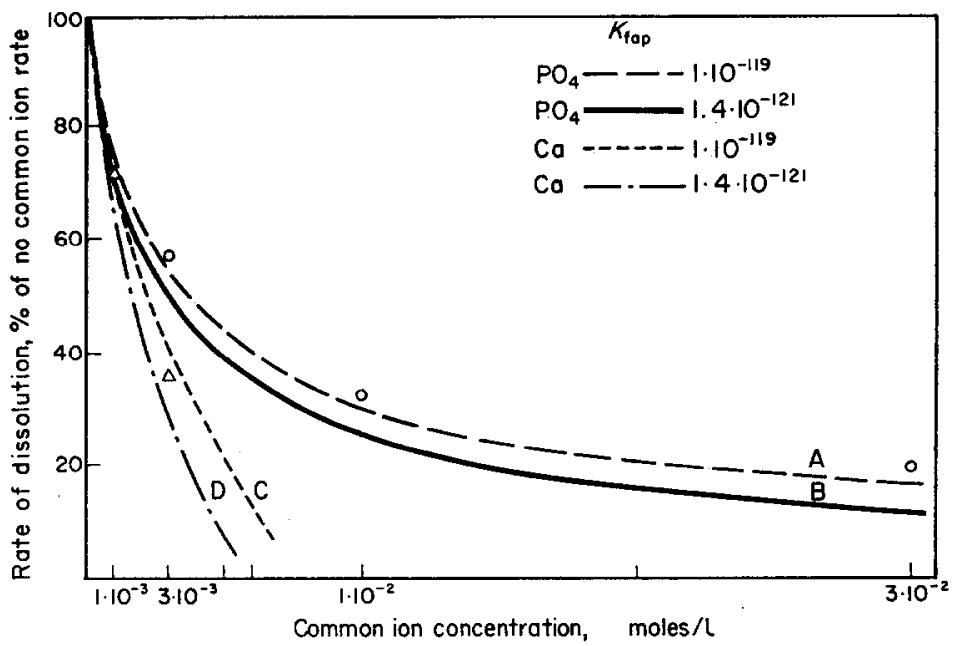

FiG. 9. Effect of common ions on the initial dissolution rate of enamel powder in $10.0 \mathrm{ppm}$ fluoride solution, $\mathrm{pH} 4 \cdot 5,0.05 \mathrm{M}$ acetate buffer. Key: $O=$ experimental data for phosphate common ions; $\Delta=$ experimental data for calcium common ions. The curves $\mathrm{A}$ and $\mathrm{B}$ represent theory for the phosphate common ion effect when $K_{\text {fap }}=$ $1 \times 10^{-119}$ and $1.4 \times 10^{-121}$ respectively, while curves $C$ and $D$ indicate theory for the calcium common ion effect when the same values of $K_{\text {fap }}$ are used $\left(1 \times 10^{-119}\right.$ and $1.4 \times 10^{-121}$. 
rate vs. common ion concentration at a particular fluoride concentration. The theoretical curves A and B which were obtained from equations (12 and 13) using $K_{\text {fap }}=$ $1 \times 10^{-119}$ and $1 \times 10^{-121}$ respectively are for the phosphate common ion effect, whereas curves $\mathrm{C}$ and $\mathrm{D}$ are for the calcium common ion effect. At both levels of fluoride $(1.0 \mathrm{ppm}$ and $10.0 \mathrm{ppm})$ and also for both calcium and phosphate ions, the experimental data fit the theory when a $K_{\text {fap }}$ value of about $1 \times 10^{-119}$ is employed.

Influence of solution fluoride upon the initial dissolution rate of enamel (no common ion present)

The experimental relative initial rates showing the effect of fluoride for enamel powder are given (open circles) in Fig. 10 (for $\mathrm{pH} \mathrm{4.5)} \mathrm{and} \mathrm{in} \mathrm{Fig.} 11$ (for $\mathrm{pH} \mathrm{6.0).}$ The ordinate for these plots refers to the ratio of the initial dissolution rate in the fluoride solution to that at zero fluoride in the medium.

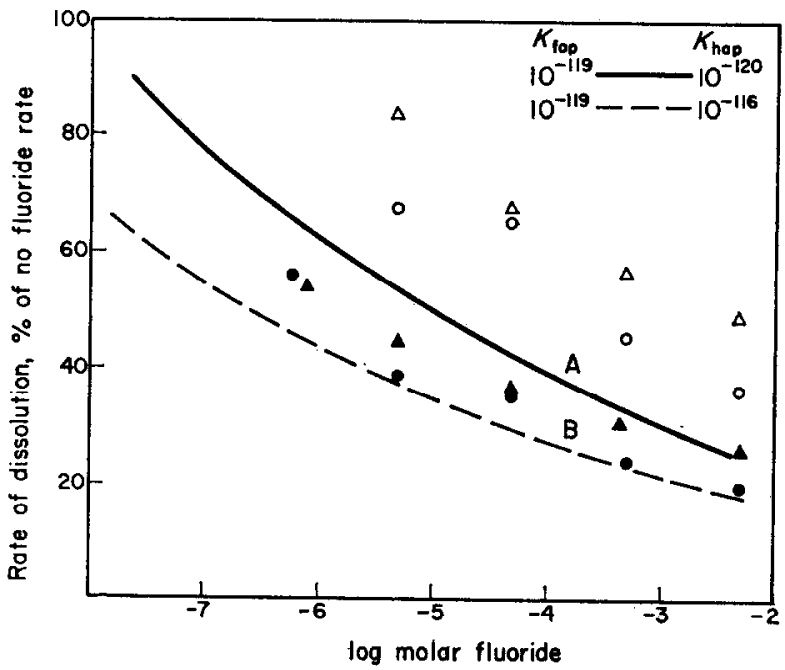

FrG. 10. Effect of solution fluoride on the initial dissolution rate of enamel powders in pH 4.5, 0.05 M acetate buffer. Key: $O=$ enamel powder; $\Delta=$ fluoride treated enamel powder; $=$ corrected enamel powder; $\boldsymbol{\Lambda}=$ corrected fluoride treated enamel powder. The curve $A$ represents theory when $K_{\text {hap }}=10^{-120}$ and $K_{\text {fap }}=1 \times 10^{-119}$, and curve B represents theory when $K_{\text {nap }}=1 \times 10^{-116}$ and $K_{\text {fap }}=1 \times 10^{-119}$.

The theoretical model predictions were calculated using the procedures described earlier for the TVA apatite experiments. The two curves shown in Figs. 10 and 11 represent these theoretical calculations employing $K_{\text {fap }}=1 \times 10^{-119}$ with $K_{\text {hap }}=$ $1 \times 10^{-116}$ and $1 \times 10^{-120}$. The $K_{\mathrm{rap}}$ value of $1 \times 10^{-119}$ was taken because this is the value that agreed best with the rate data obtained in the presence of both fluoride and common ions (see previous section and Figs. 8 and 9). For the pH 6.0 data (Fig. 11) the agreement of the experimental rates with the theory using $K_{\text {fap }}=1 \times 10^{-119}$ and $K_{\text {hap }}=1 \times 10^{-116}>1 \times 10^{-118}$ is good. For the pH 4.5 case (Fig. 10) the observed effects require a significantly lower value of $K_{\text {hap }}$ to correlate well with the model. 


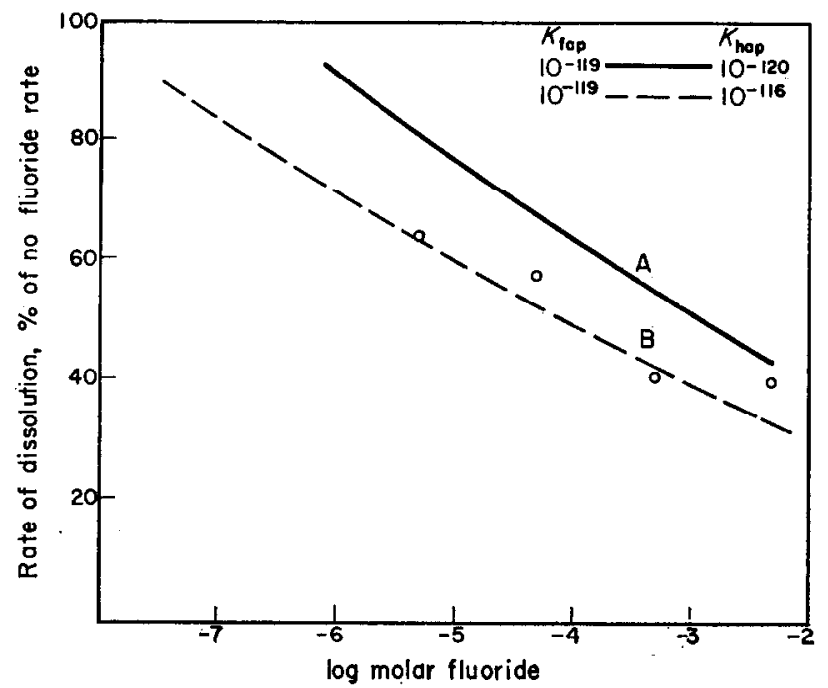

Fig. 11. Effect of solution fluoride on the initial dissolution rate of enamel powder in pH 6.0, 0.01 $\mathrm{M}$ acetate buffer. Circles are experimental data. The curve $\mathrm{A}$ represents theory when $K_{\text {fap }}=1 \times 10^{-119}$ and $K_{\text {hap }}=1 \times 10^{-120}$, while curve B represents theory when $K_{\text {fap }}=1 \times 10^{-119}$ and $K_{\text {hap }}=1 \times 10^{-116}$.

To explain this discrepancy, it is proposed that the fluoride originally present in the enamel is responsible for reducing the dissolution rates at $\mathrm{pH} 4.5$ but not significantly at $\mathrm{pH} 6 \cdot 0$. A correction calculation for the influence of fluoride originally in the enamel is presented in the following discussion.

Calculations for estimating the effect of fluoride originally in the enamel upon the dissolution rate

The enamel sample employed in these studies contained $74 \mathrm{ppm}$ of fluoride, and since there is approximately $4 \times 10^{5} \mathrm{ppm}$ of calcium in the enamel, this corresponds to $3 \cdot 7 \times 10^{-4}$ mole of fluoride per mole of calcium in the enamel.

Because of the finite concentrations of fluoride in the enamel, equation (11) is not rigorously valid. Instead one may write,

$$
D_{\mathrm{F}} \frac{\mathrm{d}\left[\mathrm{F}^{-}\right]}{\mathrm{d} x}=3.7 \times 10^{-4} D_{\mathrm{Ca}} \frac{\mathrm{d}\left[\mathrm{Ca}^{2+}\right]}{\mathrm{d} x} .
$$

Equation (14) assumes that fluoride in the original enamel is uniformly distributed and that the dissolution is congruent for this composition.

Integrating equation (14), we have

$$
D_{\mathrm{F}}\left[\left(\mathrm{F}^{-}\right)_{h}-\left(\mathrm{F}^{-}\right)_{0}\right]=3.7 \times 10^{-4} D_{\mathrm{Ca}}\left[\left(\mathrm{Ca}^{2+}\right)_{h}-\left(\mathrm{Ca}^{2+}\right)_{0}\right] .
$$

Furthermore one may write (HIGUCHI et al., 1965)

$$
-G h=D_{\mathrm{Ca}}\left[\left(\mathrm{Ca}^{2+}\right)_{h}-\left(\mathrm{Ca}^{2+}\right)_{0}\right]
$$


where $\left(\mathrm{Ca}^{2+}\right)_{0}$ is the calcium concentration at $x=0$. Thus from equations (15) and (16) one can see that even when the bulk fluoride concentration, $\left(\mathrm{F}^{-}\right)_{h}$, is zero, $\left(\mathrm{F}^{-}\right)_{0}$ may not be zero but depends upon $G h$ through equation (16).

For the case in which no fluoride or a common ion is present one may take $\left(\mathrm{F}^{-}\right)_{h}$ $=\left(\mathrm{Ca}^{2+}\right)_{h}=\mathrm{O}$. This then gives:

$$
\mathrm{D}_{\mathrm{F}}\left(\mathrm{F}^{-}\right)_{0}=3.7 \times 10^{-4} \mathrm{D}_{\mathrm{Ca}}\left(\mathrm{Ca}^{2+}\right)_{0}=3.7 \times 10^{-4} \mathrm{Gh} \text {. }
$$

By means of equations (13) and (14) of reference (HiGuCHI et al., 1969) one may calculate that at $\mathrm{pH} 4.5$ and $0.05 \mathrm{M}$ acetate buffer concentration, $G h \simeq 1.5 \times 10^{-11}$ moles of calcium/c/sec when $K_{\text {hap }}=10^{-118}$ and when the anticipated effect of $\left(\mathrm{F}^{-}\right)_{0}$ is taken into account. The value of $K_{\text {hap }}=10^{-118}$ was employed also anticipating that this correction would provide a fit with this value. With this value of $G h$, one obtains:

$$
\left(\mathrm{F}^{-}\right)_{0}=\frac{3.7 \times 10^{-4} \times 1.5 \times 10^{-11}}{1 \times 10^{-5}}=5.55 \times 10^{-10} \mathrm{moles} / \mathrm{cm}^{3}
$$

or $5 \cdot 55 \times 10^{-7}$ moles $/ 1$, which gives $\log$ fluoride $=-6 \cdot 25$. Such a surface fluoride concentration would depress the dissolution rate of a hypothetical fluoride free enamel sample by about 44 per cent under the present conditions with $K_{\text {hap }}=10^{-118}$ and $K_{\text {fap }}=10^{-119}$.

Thus the correction for this effect can be made by setting the relative rate for the control experiment i.e., the zero bulk solution fluoride experiment equal to 56 per cent at $\log$ fluoride $=-6 \cdot 25$. Then the agreement of the data from the solution fluoride experiments with the theory based upon this new reference point should constitute a better test of the model. As can be seen, the corrected enamel data (closed circles) in Fig. 10 follows the theory $\left(K_{\text {hap }} \sim 10^{-118}\right.$ and $\left.K_{\text {fap }}=10^{-119}\right)$ rather well.

In view of the above one may question the agreement of the "uncorrected" data with theory of $\mathrm{pH} 6 \cdot 0$. The following calculation shows, however, that at $\mathrm{pH} 6 \cdot 0 \mathrm{Gh}$ is small enough so that the effect of $74 \mathrm{ppm}$ fluoride in the enamel is negligible. At $\mathrm{pH}$ 6.0 and acetate buffer concentration of $0.01 \mathrm{M}$, the calculations with equations (13 and 14) of reference (HIGUCHI et al., 1969) with $K_{\text {hap }}=10^{-118}$ give $G h=2.8 \times 10^{-12}$. With this value for $G h$, equation (15) gives $\log$ fluoride $=-7 \cdot 0$. As can be seen in Fig. $11, \log$ fluoride $=-7 \cdot 0$ would correspond to a negligible reduction in rate when $K_{\text {fap }}=10^{-119}$ and $K_{\text {hap }}=10^{-118}$.

This correction procedure thus has improved the self-consistency of the data regarding $\mathrm{pH}$ effects upon the influence of fluoride on the enamel dissolution rates. Therefore while there remains some question as to whether the assumption that 74 ppm fluoride is uniformly distributed in the enamel particles, these findings are certainly strongly suggestive that the corrections are appropriate.

It will be seen in the next section that this type of correction is also consistent with other independent observations.

Influence of solution fluoride on the dissolution rate of the fluoride treated enamel powder

Figure 10 also gives the experimental results with the fluoride treated enamel (enamel F.T.). This sample contained $97 \mathrm{ppm}$ fluoride ( $74 \mathrm{ppm}$ original $+23 \mathrm{ppm}$ by 
uptake). The open triangular points give the experimental relative rates using the enamel F.T. sample data obtained in zero solution fluoride as the 100 per cent control. The closed triangular points give the corrected experimental rates based upon a calculation similar to the one given above correcting for the effect of fluoride in the original untreated enamel. $\Lambda$ gain $K_{\text {hap }}=10^{-118}$ and $K_{\text {fap }}=10^{-119}$ were employed and $\left(\mathrm{F}^{-}\right)_{0}$ was found to be $7 \cdot 5 \times 10^{-7}$ moles/l corresponding to a reduction of the rate to about 46.0 per cent of the hypothetical fluoride free enamel.

This correction procedure makes both the fluoride treated and untreated enamel data consistent with theory $\left(K_{\text {hap }} \simeq 1 \times 10^{-118}\right.$ and $\left.K_{\text {fap }}=1 \times 10^{-119}\right)$.

One must consider the question of why the earlier enamel dissolution rate studies (HIGUCHI et al., 1969) with the same sample showed that the value of $\mathrm{K}_{\text {hap }}=1 \times$ $10^{-120}$ to $1 \times 10^{-124}$ correlated well with the model, while the present studies suggest that $K_{\text {hap }} \simeq 1 \times 10^{-118}$ is a better value. This problem is resolved if it is proposed that the values of $K_{\text {hap }}=1 \times 10^{-120}$ to $1 \times 10^{-124}$ fitted the model when corrections for the effects of the small amount ( $74 \mathrm{ppm}$ ) of fluoride in the enamel were not made and that the present choice of $K_{\text {hap }} \simeq 1 \times 10^{-118}$ is based upon the hypothetical fluoride free enamel and therefore should be somewhat larger.

Influence of solution fluoride on the initial dissolution rate of the Victor sample (no common ion present)

In Figs. 12 and 13 the experimental relative dissolution rates are given, showing the effect of fluoride upon the initial dissolution rate of Victor sample in $\mathrm{pH} 4 \cdot 5,0.05$

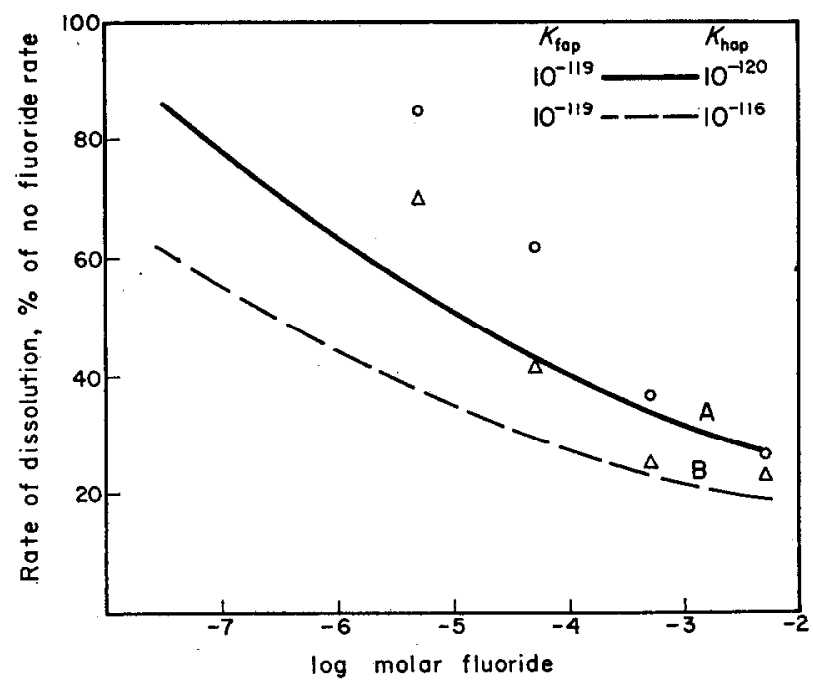

FIG. 12. Effect of solution fluoride on the initial dissolution rate of Victor apatite samples in $\mathrm{pH} 4 \cdot 5,0.05 \mathrm{M}$ acetate buffer. Key: $O=$ Victor apatite sample; $\Delta=$ Victor (15 per cent predissolved) apatite sample. The curve $A$ indicates theoretical predictions when $K_{\text {fap }}=1.0 \times 10^{-119}$ and $K_{\text {tap }}=1.0 \times 10^{-120}$, while curve B indicates theoretical predictions when $K_{\text {fap }}=1.0 \times 10^{-119}$ and $K_{\text {hap }}=1.0 \times 10^{-116}$. 


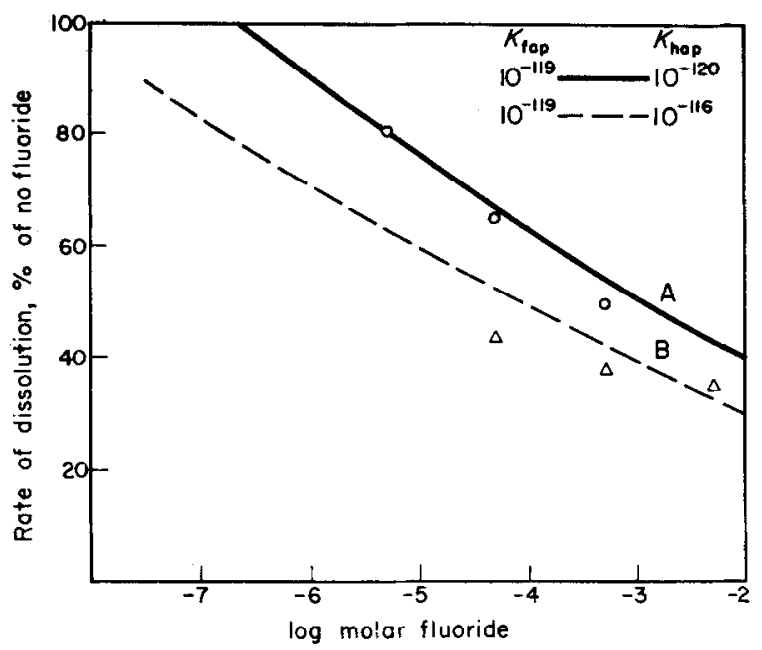

FIG. 13. Effect of solution fluoride on the initial dissolution rate of Victor apatite sample in pH $6 \cdot 0,0.01 \mathrm{M}$ acetate buffer. Key: $\mathrm{O}=$ Victor apatite sample; $\Delta=$ Victor (15 per cent predissolved) apatite sample. The curve $A$ represents theory when $K_{\text {rap }}=$ $1.0 \times 10^{-119}$ and $K_{\text {hap }}=1.0 \times 10^{-120}$, while curve B represents theory when $K_{\text {fap }}$ $=1.0 \times 10^{-119}$ and $K_{\text {hap }}=1.0 \times 10^{-116}$.

acetate buffer and $\mathrm{pH} 6 \cdot 0,0 \cdot 01 \mathrm{M}$ acetate buffer concentrations respectively. The theoretical predictions were again calculated as before. The two theoretical curves $\mathrm{A}$ and B which correspond to $K_{\text {fap }}=1 \times 10^{-119}$ with $K_{\text {hap }}=1 \times 10^{-120}$ and $1 \times 10^{-116}$ respectively.

The Victor sample was believed to be poorly crystallized and to contain some amorphous calcium phosphate other than apatite. Thus one would expect such material to be less influenced by fluoride. Prior dissolution of such material would be expected to preferentially dissolve away the non-apatite phases and give a residue that would be more influenced by fluoride. Thus the data obtained with a 15 per cent predissolved sample (shown by open triangular points in Figs. 12 and 13) show a greater fluoride influence at both $\mathrm{pH} 4 \cdot 5$ and $6 \cdot 0$.

In previous studies (HIGUCHI et al., 1969) the Victor sample did not give as good a consistency with the model as did the TVA samples. However, $K_{\text {hap }}$ values of $1 \times$ $10^{-119}$ to $1 \times 10^{-115}$ usually were found to give the best fit of the experimental data to the model. As can be seen in Figs. 12 and 13, for this range of $K_{\text {hap }}$ values, a $K_{\text {fap }}$ $=1 \times 10^{-119}$ gives reasonably good agreement between experimental data and the theory. (For a much more extensive presentation of pertinent results see N. A. Mir's $\mathrm{Ph}, \mathrm{d}$. thesis, University of Michigan).

\section{DISCUSSION}

The present approach, as was the case in the earlier studies (HrGucHI et al., 1965, 1969), involved carrying out a sufficient number of independent experiments to 
demonstrate the self-consistency of the proposed model. More specifically, for a given sample such as the enamel powder or the TVA (P.D.), a value for the fluorapatite solubility product, $K_{\text {fap }}$, was sought that would be consistent with the experiments, the model, and the preselected values for the other parameters (viz., $K_{\text {hap }}$, dissociation constants, diffusion coefficients, ctc.). Thus it has been found that a $K_{\text {hap }}$ value of $1 \times 10^{-130}$ to $1 \times 10^{-132}$ consistently described the experimental TVA (P.D.) data beyond those needed to establish it. In the case of powdered enamel a value of $K_{\text {fap }}$ $\simeq 1 \times 10^{-119}$ was found to show this consistency. In view of the large number of parameters involved it would only be in an extremely fortuitous situation to regard the good agreement between data and model as accidental.

The present model may be tested further. For example, other buffers and buffer concentrations may be utilized to see whether the same $K_{\text {fap }}$ value and the model would best describe the data. Other $\mathrm{pH}$ values may be tried also. The corresponding theoretical calculations are easily carried out.

The finding that the $K_{\text {hap }}$ and $\mathbf{K}_{\text {fap }}$ for the same apatitic sample are similar is very interesting. This supports the idea that the fluorapatite is formed by the isomorphous substitution of the surface hydroxyls by fluoride ions rather than by the precipitation of bulk fluorapatite onto the existing hydroxyapatite crystals. Were the latter to occur one would expect the $K_{\text {fap }}$ for enamel to be closer to the $K_{\text {fap }}$ for the TVA apatite. This isomorphous substitution idea is not new (MCCANN and BRUDEVoLD, 1966) and also receives independent support from studies in these laboratories (MIR, 1967) on fluoride uptake by enamel powder and TVA apatite. The experiments have shown that the uptake of fluoride is only enough to account for about a monolayer of fluorapatite on the hydroxyapatite crystals.

The surface substitution of fluoride for hydroxyls leads to the following mechanistic interpretation. In order to have the fluorapatite as the thermodynamic governing phase for dissolution and at the same time to have only about a unit cell of fluorapatite present at the surface, one must deduce that the fluoride-hydroxide substitution rate must be rapid compared to the dissolution rate. This is a reasonable situation if the activation energy for the substitution process is not too great and the dissolution rate is diffusion controlled as is assumed.

The improved correlation of the model with enamel data when the correction for the fluoride present in the enamel was made is significant because this example shows the value of the physical model approach in detecting what may be regarded as subtle discrepancies between model and experiment. While the observation was made after the fact, the procedure should be categorized as a priori since the effect was predicted by the model.

The authors suspect that the role of carbonate in the enamel should be investigated similarly. This may lead to a new $K_{\text {hap }}$ value called a hypothetical fluoride and carbonate free enamel.

Thus far the present investigations and those reported earlier (HIGUCHI et al., 1965, 1969) have given much encouragement to the basic approach initiated by the authors. The studies completed to date will serve as "base lines" for the more complex situations anticipated. 
Acknowledgements-The technical assistance of S. VALVANI in the earlier phase of this research, is gratefully acknowledged. This study was supported partly by USPHS research grant DE-01830 from the NIDR, NIH, Bethesda, Md., and partly by a grant from the Bristol Myers Company.

Résumé-Des équations ont été établies pour estimer les vitesses de déminéralisation de l'émail dentaire, en employant le modèle "fluoroapatite". Ce modèle suppose que lorsque l'hydroxyle-apatite est soumis à une faible quantité de fluor, une couche de fluoroapatite est formée autour du cristal d'apatite et ce fluoroapatite est considéré comme la phase thermodynamique déterminante pendant la dissolution. Les vitesses de déminéralisation ont été déterminées en fonctions de la concentration ionique en fluor, de la concentration en ion hydrogène, de la concentration tampon globale, des coefficients de diffusion de toutes les espèces intéressées, de la constante de dissociation du tampon acide $\left(K_{\mathrm{a}}\right)$ et des produits de solubilité des fluoro et des hydroxyle-apatites.

Le modèle "fluoroapatite" a été étudiée de façon critique à l'aide de résultats expérimentaux obtenus avec des apatites synthétiques et de la poudre d'émail. Les expériences ont été menées comme une fonction de la concentration de la solution fluorée, des ions communs (calcium et phosphate) et du pH. Par l'échantillon synthétique, TVA (P.D.), les expériences concordent quantitativement avec le modele lorsqu'une valeur du produit de solubilité du fluoroapatite de $1 \times 10^{-130} \mathrm{à} 1 \times 10^{-132}$ est utilisée. Pour la poudre d'émail, des valeurs de $K_{\mathrm{fap}} \simeq 1 \times 10^{-119}$ et $K_{\mathrm{hap}} \simeq 1 \times 10^{-118}$ concordent bien avec les faits expérimentaux. Il a été nécessaire de tenir compte du fluor, initialement présent dans l'émail, pour arriver à une bonne concordance des résultats avec le modèle.

La phase "fluoroapatite" est considérée comme étant formée par substitution isomorphique des hydroxyles de surface par le fluor, plutôt que comme une reprécipitation d'une "vraie" phase de fluoroapatite sur l'hydroxyleapatite initial.

Ces résultats sont en accord avec ceux de HigucHr et al. (1965; 1969). Un modèle physique unique, choisi a priori, a ainsi décrit les résultats expérimentaux sur les vitesses de dissolution de l'émail et de l'apatite synthétique.

Zusammenfassung-Unter Verwendung des "Fluorapatit"-Modells wurden für die Demineralisationsraten des Zahnschmelzes Gleichungen abgeleitet und Berechnungen ausgeführt. Das Modell setzt voraus, daß, wenn Hydroxylapatit einer niedrigen Fluoridkonzentration ausgesetzt wird, eine Fluorapatitschicht um das Apatitkristall herum gebildet wird; weiterhin wird angenommen, daß diese Fluorapatitbildung die thermodynamisch bestimmte Phase während der Auflösung ist. Die Demineralisationsraten stellten sich als Funktion der Fluoridionenkonzentration, der Wasserstoffionenkonzentration, der Gesamtpufferkonzentration, der Diffusionskoeffizienten aller untersuchten Spezies, der Dissoziationskonstante der Puffersäure $\left(K_{\mathrm{a}}\right)$ und der Löslichkeitsprodukte des Fluorapatits und des Hydroxylapatits dar.

Das "Fluorapatit"-Modell wurde mit Hilfeder experimentellen Daten kritisch untersucht, die mit synthetischen Apatiten und zermahlenem Schmelz erhalten worden waren. Die Versuche wurden als eine Funktion der Fluoridkonzentration in der Lösung, der allgemeinen Ionen (Kalzium und Phosphat) und des $\mathrm{pH}$ ausgeführt. Bei der synthetischen Probe TVA (P.D.) stimmten alle Versuche mit dem Modell quantitativ überein, wenn ein Fluorapatit-Löslichkeitsprodukt von $1 \times 10^{-130}$ bis $1 \times 10^{-132}$ in Verbindung mit einem Hydroxylapatit-Löslichkeitsprodukt von $1 \times 10^{-130}$ bis $1 \times 10^{-132}$ eingehalten wurde. Bei den Untersuchungen mit zermahlenem Schmelz stimmten Werte von $K_{\text {fap }} \simeq 1 \times 10^{-119}$ und $K_{\text {hap }} \simeq 1 \times 10^{-118}$ gut mit den Experimenten überein. Es war nötig, den Einfluß des anfangs in den Schmelzproben vorhandenen Fluorids zu berücksichtigen, um die beste Übereinstimmung mit dem Modell zu erzielen.

Die "Fluorapatit"-Phase dürfte eher durch isomorphe Substitution der Oberflächenhydroxyle durch Fluorid als durch Wiederausfällung einer "wahren" Fluorapatitphase auf den ursprünglichen Hydroxylapatitkristallen zu erklären sein.

Diese Untersuchungen stimmen mit früher veröffentlichten überein (HIGUCHI et al., 1965; 1969). Daher kann angenommen werden, daß ein einziges physikalisches $a$ priori-Modell, wie beschrieben, in gleicher Weise alle experimentellen Daten über die Auflösungsraten von Schmelz und synthetischem Apatit umfaßt. 


\section{REFERENCES}

Brudevold, F., Hein, J. W., Bonner, J. F., Nevin, R. B., Bibby, B. G. and Hodgr, H. C. 1957. Reaction of tooth surfaces with one ppm of fluoride as sodium fluoride. J. dent. Res. 36, 771-779.

Brudevold, F., Savory, A., Gardner, D. E., SPINelli, M. and SpIers, R. 1963. A study of acidulated fluoride solutions-1. Archs oral. biol. 8, 179-182.

Gray, J. A. 1965. Acid dissolution rate of sound and white spot enamel treated with tin II and fluoride compounds. J. dent. Res. 44, 497-501.

Higuchi, W. I., Gray, J. A., Hefferren, J. J. and Patel, P. R. 1965. Mechanism of enamel dissolution in acid buffers. J. dent. Res. 44, 330-341.

Higuchi, W. I., Mrr, N. A., Patel, P. R., Becker, J. W. and Hefferren, J. J. 1969. Quantitation of enamel demineralization mechanisms III. J. dent. Res. in press.

Jenkins, G. N. 1966. Physiology of the Mouth (3rd ed.) Davis, Philadelphia.

Knutson, J. W. and Armstrong, W. D. 1943. The effect of topically applied sodium fluoride on dental caries experience. Publ. Hlth Rep. 58, 1701-1715.

LEACH, S. A. 1959. Reactions of fluoride with powdered enamel and dentine. Br. dent. J. 106, 133-142.

Malaowalla, A. and Myers, H. M. 1962. Interaction of sodium fluoride and synthetic apatite. J. dent. Res. 41, 413-419.

MANLY, R. S. and BrBby, B. G. 1949. Substances capable of decreasing the acid solubility of tooth enamel. J. dent. Res. 28, 160-171.

MCCANN, H. G. 1953. Reactions of fluoridc ion with hydroxyapatite. J. biol. Chem. 201, 247.

MCCANN, H. G. and Brudevold, F. 1966. The mechanism of the caries-inhibiting effect of fluoride. In: Environmental Variables in Oral Disease (Edited by KRESHOVER, J. and MCClure, F. J.) pp. 103-128. American Association for the Advancement of Science. Washington, D.C.

MIR, N. A. 1967. The mechanism of action of solution fluoride upon the demineralization rate of enamel. Ph.D. Thesis, Univ. of Michigan.

VolKer, J. F. 1939. Effect of fluorine on solubility of enamel and dentin. Proc. Soc. exp. Biol. 42, $725-727$.

Walsh, R. H., Nebergall, W. H., MuHLer, J. C. and Day, H. G. 1957. Effects of buffered solutions of sodium fluoride and stannous fluoride on the solubility of powdered enamel using repeated decalcification. J. dent. Res. 36, 118-123. 